Prepared in cooperation with the Upper San Pedro Partnership

Simulated Effects of Ground-Water Withdrawals and Artificial Recharge on Discharge to Streams, Springs, and Riparian Vegetation in the Sierra Vista Subwatershed of the Upper San Pedro Basin, Southeastern Arizona

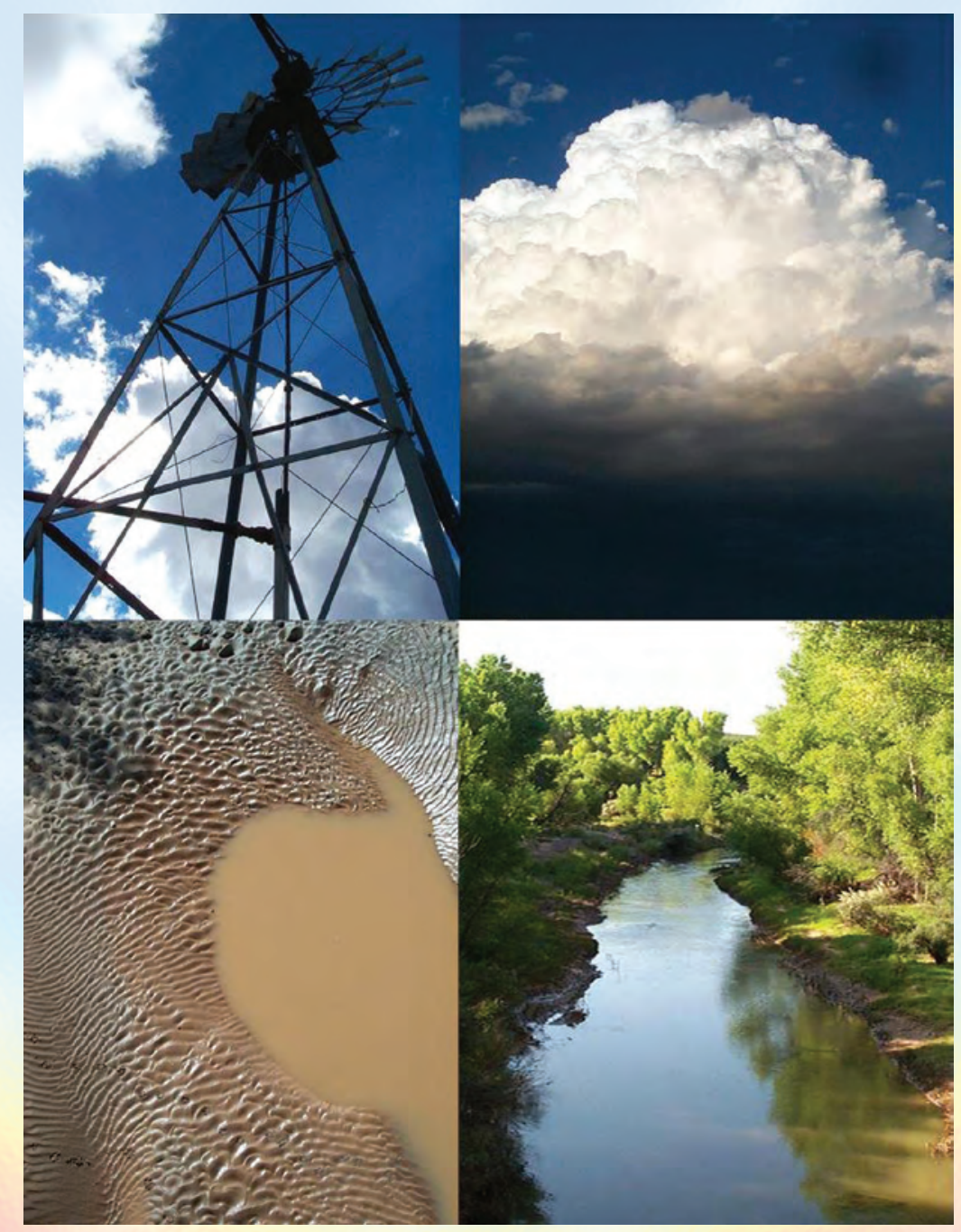

Scientific Investigations Report 2008-5207

Version 1.1, April 2014 
This page left intentionally blank. 


\section{Simulated Effects of Ground-Water Withdrawals and Artificial Recharge on Discharge to Streams, Springs, and Riparian Vegetation in the Sierra Vista Subwatershed of the Upper San Pedro Basin, Southeastern Arizona}

By Stanley A. Leake, Donald R. Pool, and James M. Leenhouts

Prepared in cooperation with the Upper San Pedro Partnership

Scientific Investigations Report 2008-5207

Version 1.1, April 2014 


\section{U.S. Department of the Interior DIRK KEMPTHORNE, Secretary}

\section{U.S. Geological Survey \\ Mark D. Myers, Director}

\section{U.S. Geological Survey, Reston, Virginia}

First release: 2008

Revised: April 2014 (ver. 1.1)

This report and any updates to it are available online at:

http://pubs.usgs.gov/sir/2008/5207/

For product and ordering information:

World Wide Web: http://www.usgs.gov/pubprod

Telephone: 1-888-ASK-USGS

For more information on the USGS - the Federal source for science about the Earth, its natural and living resources, natural hazards, and the environment:

World Wide Web: http://www.usgs.gov

Telephone: 1-888-ASK-USGS

Any use of trade, product, or firm names is for descriptive purposes only and does not imply endorsement by the U.S. Government.

Although this report is in the public domain, permission must be secured from the individual copyright owners to reproduce any copyrighted materials contained within this report.

Suggested citation:

Leake, S.A., Pool, D.R., and Leenhouts, J.M., 2008, Simulated effects of ground-water withdrawals and artificial recharge on discharge to streams, springs, and riparian vegetation in the Sierra Vista Subwatershed of the Upper San Pedro Basin, southeastern Arizona (ver. 1.1, April 2014): U.S. Geological Survey Scientific Investigations Report 2008-5207, 14 p.

Produced in the Western Region, Menlo Park, California

Manuscript approved for publication, October 29, 2008

Text edited by Peter H. Stauffer

Layout by David R. Jones 


\section{Contents}

Abstract

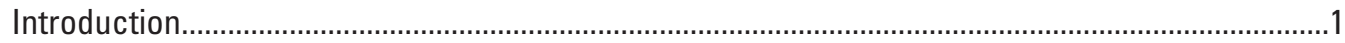

Method and Considerations for Constructing Capture Maps ......................................................

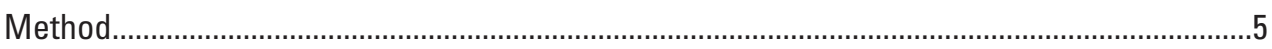

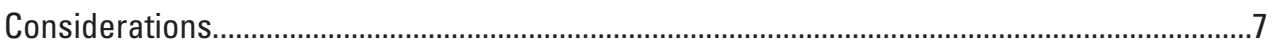

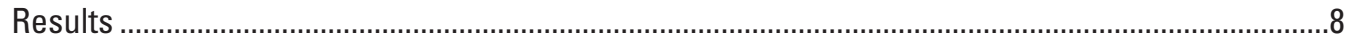

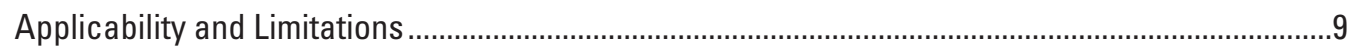

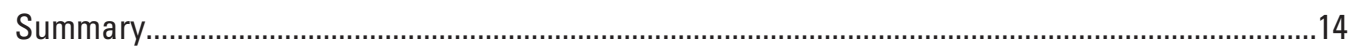

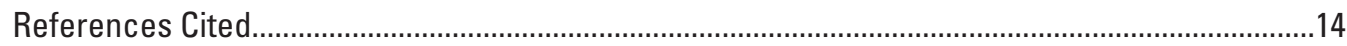

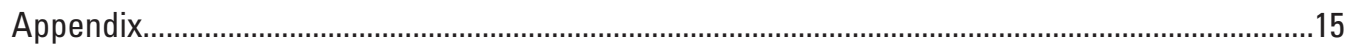

\section{Figures}

1. Location of modeled area and model boundary conditions ........................................................

2. Generalized hydrogeologic section and extent of numerical model layers, Upper San Pedro Basin, United States and Mexico .................................................................

3. Example capture and storage fraction curves computed by the Upper San Pedro model using discharge rates of 100 and 1,000 cubic meters per day .......................................

$4 A$. Computed capture of streamflow, riparian evapotranspiration, and springflow that would result for withdrawal of water from model

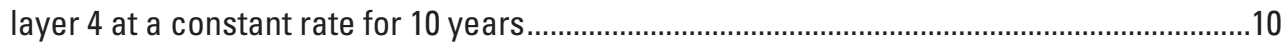

$4 B$. Computed capture of streamflow, riparian evapotranspiration, and springflow that would result for withdrawal of water from model layer 4 at a constant rate for 50 years...

$5 A$. Computed increase of streamflow, riparian evapotranspiration, and springflow that would result for recharge of water to the uppermost model layer at a constant rate for 10 years.

$5 B$. Computed increase of streamflow, riparian evapotranspiration, and springflow that would result for recharge of water to the uppermost model layer at a constant rate for 50 years.

A1. Computed capture of streamflow, riparian evapotranspiration, and springflow that would result for withdrawal of water from model layer 4 at a constant rate for 100 years. 


\section{Conversion Factors}

\begin{tabular}{|c|c|c|}
\hline Multiply & By & To obtain \\
\hline \multicolumn{3}{|c|}{ Length } \\
\hline meter (m) & 3.281 & foot (ft) \\
\hline kilometer (km) & 0.6214 & mile (mi) \\
\hline \multicolumn{3}{|c|}{ Area } \\
\hline square meter $\left(\mathrm{m}^{2}\right)$ & 0.0002471 & acre \\
\hline square kilometer $\left(\mathrm{km}^{2}\right)$ & 0.3861 & square mile $\left(\mathrm{mi}^{2}\right)$ \\
\hline \multicolumn{3}{|c|}{ Flow rate } \\
\hline cubic meter per day $\left(\mathrm{m}^{3} / \mathrm{d}\right)$ & 0.0004087 & cubic foot per second $\left(\mathrm{ft}^{3} / \mathrm{s}\right)$ \\
\hline cubic meter per day $\left(\mathrm{m}^{3} / \mathrm{d}\right)$ & 264.2 & gallon per day (gal/d) \\
\hline cubic meter per day $\left(\mathrm{m}^{3} / \mathrm{d}\right)$ & 0.2961 & gallon per minute (gal/min) \\
\hline cubic meter per day $\left(\mathrm{m}^{3} / \mathrm{d}\right)$ & 0.1834 & acre-foot per year \\
\hline \multicolumn{3}{|c|}{ Recharge and evapotranspiration rate } \\
\hline meter per day (m/d) & 3.281 & foot per day (ft/d) \\
\hline \multicolumn{3}{|c|}{ Hydraulic conductivity } \\
\hline meter per day (m/d) & 3.281 & foot per day (ft/d) \\
\hline \multicolumn{3}{|c|}{ Specific storage } \\
\hline per meter $\left(\mathrm{m}^{-1}\right)$ & 0.3048 & per foot $\left(\mathrm{ft}^{-1}\right)$ \\
\hline
\end{tabular}

Vertical coordinate information is referenced to the North American Vertical Datum of 1988 (NAVD 88).

Horizontal coordinate information is referenced to North American Datum of 1983 (NAD 83).

Altitude, as used in this report, refers to distance above the vertical datum. 


\title{
Simulated Effects of Ground-Water Withdrawals and Artificial Recharge on Discharge to Streams, Springs, and Riparian Vegetation in the Sierra Vista Subwatershed of the Upper San Pedro Basin, Southeastern Arizona
}

\author{
By Stanley A. Leake, Donald R. Pool, and James M. Leenhouts
}

\section{Abstract}

In the context of ground-water resources, “capture” or "streamflow depletion" refers to withdrawal-induced changes in inflow to or outflow from an aquifer. These concepts are helpful in understanding the effects of long-term development of ground-water resources. For the Upper San Pedro Basin in Arizona, USA and Sonora, Mexico, a recently developed ground-water flow model is available to help quantify capture of water from the river and riparian system. A common method of analysis is to compute curves of capture and aquifer-storage change for a range of time at select points of interest. This study, however, presents results of a method to show spatial distributions of total change in inflow and outflow from withdrawal or injection for select times of interest. The mapped areal distributions show the effect of a single well in terms of the ratio of the change in boundary flow rate to rate of withdrawal or injection by the well. To the extent that the system responds linearly to ground-water withdrawal or injection, fractional responses in the mapped distributions can be used to quantify response for any withdrawal or injection rate. Capture distributions calculated using the Upper San Pedro model include response to (1) withdrawal in the lower basin-fill aquifer for times of 10 and 50 years following the initiation of pumping from predevelopment conditions and (2) artificial recharge to the water table in the area underlain by the lower basin-fill aquifer after 10 and 50 years. The mapped distributions show that response to withdrawals and injections is greatest near the river/riparian system. Presence of clay layers in the vertical interval between withdrawal locations and the river/riparian system, however, can delay the response.

\section{Introduction}

Ground water is an important and valuable resource, particularly in developed areas with limited or fully appropriated surface-water supplies. Withdrawal of ground water, however, can have undesirable consequences, one of which is loss of water in streams, wetlands, and riparian systems that are connected to the aquifer. The change in rates of inflow and outflow induced by withdrawing ground water is referred to as "capture" in this report. Concepts of capture, also referred to as "streamflow depletion," were first clearly articulated by Theis (1940). He observed that all water withdrawn by a well is balanced by a loss of water from somewhere. Immediately after a well begins withdrawing water, all of the loss comes from storage around the well. As time progresses, the cone of depression around a well can expand to areas of recharge and discharge, possibly resulting in increases in inflow to an aquifer, decreases in outflow from an aquifer, or a combination of both. Increases in inflow can result from increased hydraulic gradients away from losing streams or other surface-water bodies, lowering of a water table at or near the land surface that allows previously rejected recharge to infiltrate and enter the groundwater system, and movement of a ground-water divide away from the withdrawal location. Decreases in outflow can result from decreased hydraulic gradients toward gaining streams or other surface-water bodies and aquifers that may lie adjacent to the aquifer of interest. Capture can be computed by analytical solutions (see, for example, Glover and Balmer, 1954), but in flow systems with complex aquifer and surface-water geometry and aquifer heterogeneity, such as the Upper San Pedro Basin, numerical ground-water models are commonly used.

The concept of streamflow capture has particular relevance in the Upper San Pedro Basin because the area hosts both a growing population dependent on ground water and a federally protected riparian system, the San Pedro Riparian National Conservation Area (SPRNCA). This conservation area was designated by Congress in 1988 as the first riparian national conservation area in the nation and is managed under the auspices of the Bureau of Land Management. Long-term sustainability of this riparian system is directly dependent on base flow and shallow near-stream ground-water levels.

The Upper San Pedro Basin is divided into the Sierra Vista and Benson Subwatersheds; most of the SPRNCA is contained within the Sierra Vista Subwatershed (fig. 1). The largest municipalities in the subwatershed are Sierra Vista, Bisbee, Tombstone, and Huachuca City. While these areas are increasing in population, development distributed in rural parts of the watershed is also increasing. The U.S. Army post Fort Huachuca is also an important component of the economy within the Sierra Vista Subwatershed and in southern Arizona 
in general. Currently, water outflow from the subwatershed, including water withdrawn by pumping, exceeds natural inflow to the regional aquifer within the subwatershed. As a result, ground-water levels in parts of the subwatershed are declining and ground-water storage is being depleted. The continued decline of ground-water levels upgradient from perennial river reaches will eventually diminish the base flow of the San Pedro River and imperil the riparian ecosystem within the SPRNCA.

Residents of the subwatershed have responded to these water issues by forming the Upper San Pedro Partnership. The Partnership is a consortium of 21 agencies and organizations formed to ensure long-term water needs are met, both for the residents of Sierra Vista Subwatershed and for the portion of the SPRNCA within the subwatershed. The Partnership has identified that an understanding of the timing and spatial distribution of capture processes is an important aspect of resource management in the subwatershed.

The capture analysis presented in this report uses a previously constructed ground-water flow model of the Upper San Pedro Basin (Pool and Dickinson, 2007), which is briefly described here. The ground-water flow model was constructed for the purpose of simulating regional ground-water flow, including discharge to the San Pedro River and riparian vegetation. The model starts in time with predevelopment conditions and simulates changes to the system from 1902 to 2003. The primary regional aquifer in the Upper San Pedro Basin comprises thick alluvial deposits, basin fill that occupies a structural basin between sedimentary and crystalline rocks in the surrounding mountains. Other locally important aquifers include limestone and other sedimentary rocks in the surrounding mountains and underlying the alluvial deposits. Important rock units that bound the aquifer include granite and volcanic rocks that occur at the eastern extent of the Huachuca Mountains, the Tombstone Hills, and Dragoon Mountains (fig. 1). The basin fill is subdivided into upper highly permeable and lower less permeable parts that are collectively a few hundred meters thick. A significant silt and clay layer that vertically spans parts of the upper and lower basin fill (fig. 2) separates the aquifer into deep confined and shallow unconfined parts. The silt and clay layer generally lies in the basin center throughout most of the north-south extent of the basin fill, but it lies west of the San Pedro River in the region north of Highway 90, underlies the river between Palominas and Hereford, and underlies much of the river in Mexico. Highly permeable alluvium of limited saturated thickness, about $10 \mathrm{~m}$ or less, underlies the floodplain of the San Pedro River and overlies the silt and clay in the Sierra Vista Subwatershed. The stream alluvium, basin fill, and local aquifers form a single aquifer system that transmits water from the primary recharge areas near the mountains to discharge areas near the San Pedro River where ground water discharges to the stream, riparian vegetation, and springs. Ground water preferentially flows around, below, and over the locally extensive confining units of granite, volcanic rock, and silt and clay before discharging near the San Pedro River (Pool and Dickinson, 2007).

Ground-water flow was simulated using MOD-

FLOW-2000 (MF2K) (Harbaugh and others, 2000a,b), which uses finite-difference numerical methods to solve the groundwater flow equation throughout a discretized three-dimensional grid representing the aquifer system. MF2K is a modular modeling system that has many processes and packages available to simulate many possible conditions that might affect groundwater flow. Simulation of various features in the ground-water flow system in the study area was done using the Recharge (RCH), Drain (DRN), Streamflow Routing (STR1; Prudic, 1989), Evapotranspiration (EVT) and Well (WEL) Packages.

The model simulates the ground-water flow system within the portion of the Upper San Pedro Basin in Mexico, the Sierra Vista Subwatershed in the United States, and a small portion of the Benson Subwatershed that lies north of the Babocomari River and between the Mustang Mountains and the San Pedro River (fig. 1). The upper boundary is simulated as a water-table aquifer with evapotranspiration, streams, and springs. Simulated boundary conditions include no flow at the lower model boundary and along most of the lateral model boundaries and specified head at the subwatershed outflow. No-flow conditions were assumed to occur at more than $1,500 \mathrm{~m}$ below land surface, at the surface-water divide defining the periphery of the Upper San Pedro Basin, and at outcrops of impermeable rock along the northern model boundary near the San Pedro River. No-flow conditions were also assumed to occur along two ground-water flow paths at the northern boundary of the model — between the outcrops of impermeable rock near the San Pedro River and the drainage divide in the Whetstone Mountains, and along a portion of the northern subwatershed boundary that extends from near the Dragoon Mountains to the streamflow-gaging station near Tombstone. A portion of the northern model boundary between outcrops of impermeable rock near the San Pedro River was simulated as a specified-head flow boundary.

The model domain is discretized into a grid of 440 rows and 320 columns in the horizontal dimensions (fig. 1) and 5 layers in the vertical dimension (fig. 2). Horizontal discretization was $250 \mathrm{~m}$ throughout the model extent. The model domain was discretized vertically among 5 layers through which ground-water flow is primarily horizontal through laterally extensive hydrogeologic units (fig. 2). The areal extent of each model layer was set to the area over which the estimated saturated thickness of represented hydrogeologic units is $10 \mathrm{~m}$ or more. Where a layer was fully saturated, the saturated thickness is the difference between the layer top and bottom elevations. Elsewhere, saturated thickness is the difference between the elevation of the water level (or water table) and the elevation of the layer bottom. Water levels used in estimates of saturated thickness were interpolated and extrapolated from measurements from 2002 in the USGS and ADWR databases and available water levels in Mexico that are documented in a hydrogeology report completed for the mines at Cananea (Consultores en Agua Subterranea S.A. for Mexicana de Cananea, S.A. de C.V., 2000). Layer 5 (the lowest layer) encompasses the entire simulated area and represents the limestone and other sedimentary rock aquifers and confining units of granite and volcanic rocks. Layer 4 is reduced in geographic extent relative to layer 5 and represents the primary permeable parts of the 


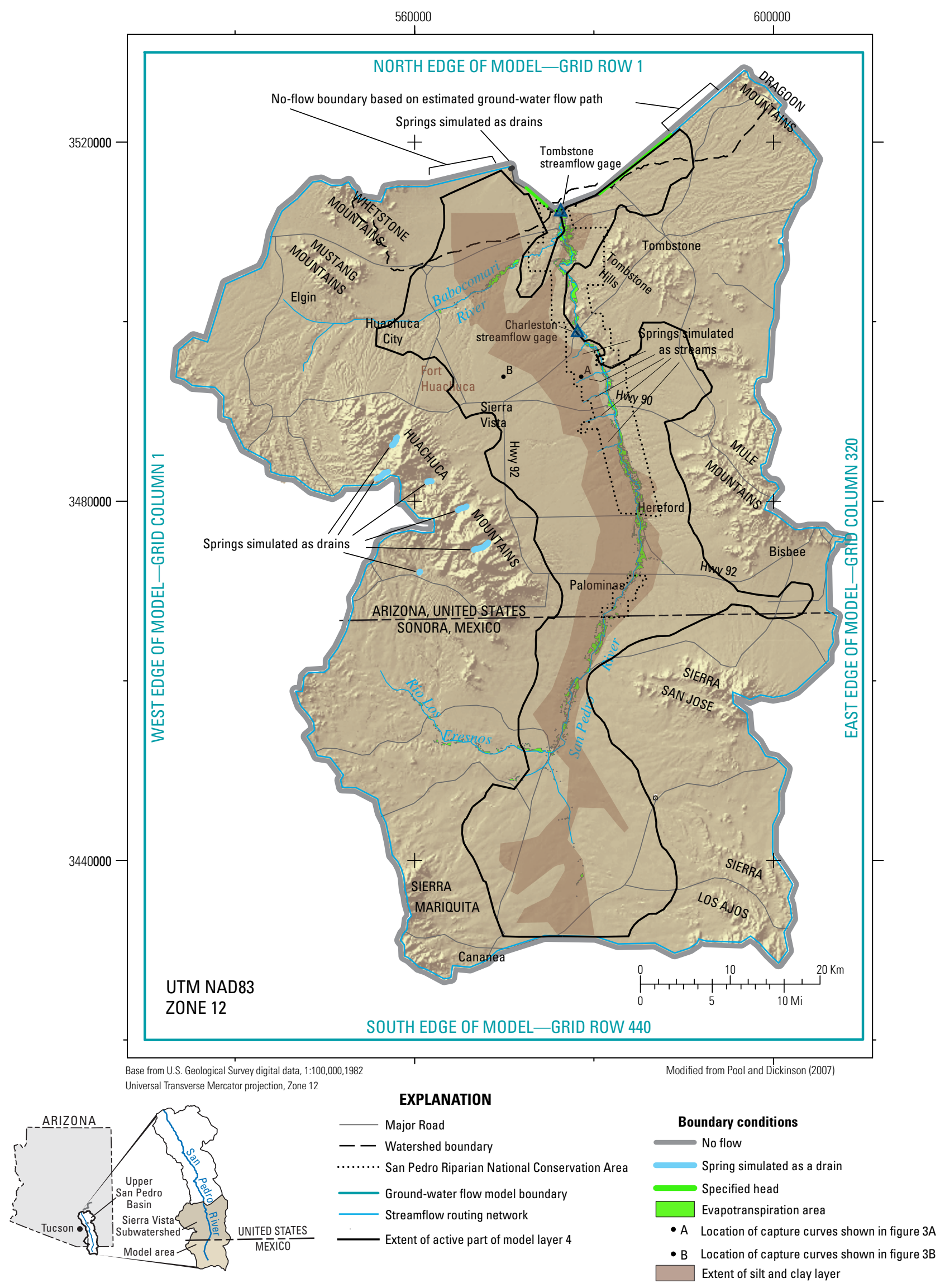

Figure 1. Location of modeled area and model boundary conditions. 
lower basin fill in the Sierra Vista Subwatershed, including sand, gravel, and conglomerate that lie adjacent to and beneath the silt and clay layer; most wells in the basin withdraw ground water from this layer. Layer 4 in Mexico represents the entire thickness of basin fill, including the silt and clay layer. Layers 2 and 3 are further reduced in geographic extent and represent the silt and clay layer and adjacent regions of more permeable basin fill within the upper and lower basin fill in the Sierra Vista Subwatershed. Layer 1 covers the smallest area and represents saturated stream alluvium along the San Pedro River and saturated basin fill that overlies the silt and clay layer in the Sierra Vista Subwatershed.

Saturated thicknesses of the layers are less than or equal to the maximum simulated thicknesses of 1,500 $\mathrm{m}$ in layer 5, $400 \mathrm{~m}$ in layer $4,170 \mathrm{~m}$ in layer 3,300 $\mathrm{m}$ in layer 2, and $100 \mathrm{~m}$ in layer 1 . The simulated thickness of layer 5 was between 1,100 and $1,490 \mathrm{~m}$ where it is overlain by layer 4 . Layer 4 ranges from 10 to $400 \mathrm{~m}$ in thickness. The thickness of layer 3 varies between 10 and $130 \mathrm{~m}$. Layer 2 was generally less than $180 \mathrm{~m}$ in thickness except in a region near Palominas, where the layer was as much as $310 \mathrm{~m}$ thick. Layer 1 was 10 to $100 \mathrm{~m}$ thick where the layer represents sand and gravel overlying the silt and clay layer near Highway 90 and 3 to 10 $\mathrm{m}$ thick along the San Pedro River, where the layer represents only the stream alluvium.

Hydraulic-conductivity values were assigned to subregions of various rock types. Granite and metamorphic rocks were assigned values ranging from 0.0001 to $0.050 \mathrm{~m} / \mathrm{d}$. Other sedimentary rocks were simulated as 0.0013 to $0.63 \mathrm{~m} / \mathrm{d}$. Basin fill included a range of values from 0.00025 to $5.0 \mathrm{~m} / \mathrm{d}$ for sand and gravel in the lower basin fill (conglomerate), 0.02 to $5.0 \mathrm{~m} / \mathrm{d}$ for sand and gravel in the upper basin fill, 0.001 to $0.01 \mathrm{~m} / \mathrm{d}$ for the silt and clay layer of the lower basin fill, 0.02 to $1.0 \mathrm{~m} / \mathrm{d}$ for silt- and clay-dominated intervals in the upper basin fill; regions of interbedded basin fill were assigned values of 0.01 to $4.0 \mathrm{~m} / \mathrm{d}$ in the lower basin fill and 2.0 to $5.0 \mathrm{~m} / \mathrm{d}$ in the upper basin fill. Stream alluvium was assigned values of 0.5 to $7.5 \mathrm{~m} / \mathrm{d}$. Anisotropy factors in the horizontal direction were 1-to-1 throughout the model. Vertical anisotropy values $\left(\mathrm{K}_{\mathrm{h}} / \mathrm{K}_{\mathrm{v}}\right)$ range from $0.5 \mathrm{in}$ some parts of the aquifer system dominated by sand and gravel to 122.5 in the silt and clay layer.

Aquifer specific storage used in confined portions of model layers ranges from $1.0 \times 10^{-6} \mathrm{~m}^{-1}$ to $2.0 \times 10^{-5} \mathrm{~m}^{-1}$. Aquifer specific yield used in unconfined portions of model layers ranges from 0.001 to 0.30 . Specific yield for crystalline rocks and low-permeability sedimentary rocks in layer 5 was assigned values of 0.001 to 0.01 . Limestone was assigned a specific yield value of 0.01 to 0.02 . Sandstone was assigned specific yield values of 0.01 to 0.20 . Specific-yield values for the lower basin fill of layer 4 range from 0.05 in areas of consolidated basin fill to 0.25 in areas of sand and gravel. Specific-yield values for basin fill of layers 2 and 3 range from 0.05 in areas of silt and clay to 0.25 in areas of sand and gravel. Specific yield of layer 1 is 0.30 in areas where the layer represents basin fill and stream alluvium.

Recharge to the aquifer system is distributed in areas of limestone and other sedimentary rocks in the mountains, near the mountain front, and on the alluvial surface. Mountainfront recharge was distributed within $1.6 \mathrm{~km}$ of the mountains. Simulated rates of predevelopment natural recharge range from $1.0 \times 10^{-6} \mathrm{~m} / \mathrm{d}$ to $2.2 \times 10^{-5} \mathrm{~m} / \mathrm{d}$ in areas of sedimentary rocks, $2.0 \times 10^{-5}$ to $1.35 \times 10^{-4} \mathrm{~m} / \mathrm{d}$ at mountain fronts, and $1.0 \times 10^{-6} \mathrm{~m} / \mathrm{d}$ across the remainder of the alluvial surface.

Evapotranspiration from riparian vegetation was simulated near the San Pedro and Babocomari Rivers. Simulation of evapotranspiration using MODFLOW requires three types of input data: evapotranspiration surface elevation, maximum evapotranspiration rate, and extinction depth. The evapotranspi-

EXPLANATION

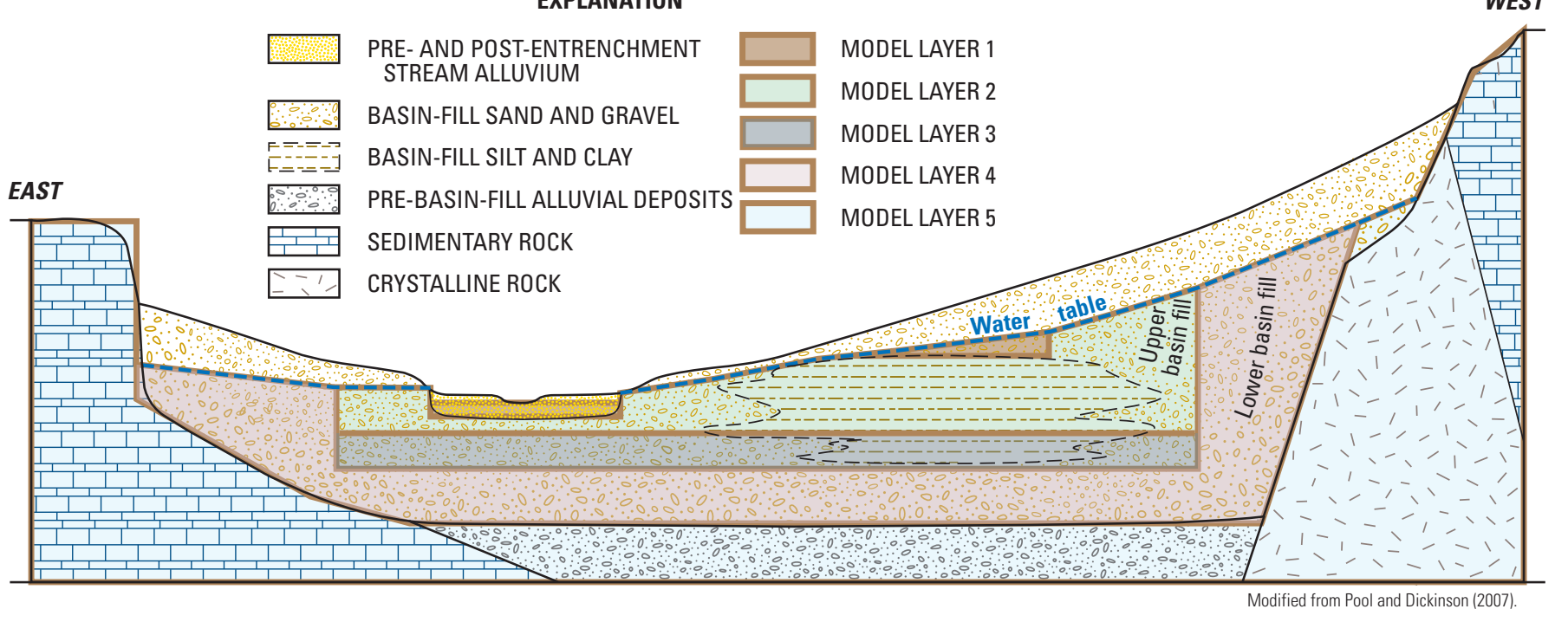

Figure 2. Generalized hydrogeologic section and extent of numerical model layers, Upper San Pedro basin, United States and Mexico. 
ration surface was assigned to each model grid as $1.5 \mathrm{~m}$ below average land-surface altitude within each 250-by-250-m model grid cell. Evapotranspiration rates were assigned to the uppermost active model layer at each evapotranspiration cell; this was predominantly layer 1 along the San Pedro River in the Sierra Vista subwatershed; layers 2, 4, and 5 along the Babocomari River; and layers 4 and 5 in Mexico. Maximum rates of evapotranspiration were $1.3 \times 10^{-3}$ and $5.2 \times 10^{-5} \mathrm{~m} / \mathrm{d}$ for mesquite and riparian woodland, respectively. Extinction depths were 6 and $14 \mathrm{~m}$ for riparian woodland and mesquite, respectively.

Ground-water discharge to streams was simulated using the MODFLOW streamflow-routing package STR1 (Prudic, 1989). Input to the package as it was implemented required stage, elevation of the bottom of the streambed, elevation of the top of the streambed, conductance, width, slope, sinuosity, and Manning's roughness coefficient. Streams in the model area were simulated using a network of channels along the San Pedro and Babocomari Rivers and several tributaries that include springs that could contribute to surface flow in the San Pedro River. The stream network extends from the model outflow near the streamflow-gaging station near Tombstone on the San Pedro River to north of Cananea on the San Pedro River. The simulated portion of the Babocomari River extends from the confluence with the San Pedro River to near Elgin. Several ephemeral streams west of the San Pedro River were simulated as tributary streams because several springs issue from the regional aquifer along their channels.

Simulated streams were divided into 99 segments and each segment was further divided into reaches. Each segment was assigned top and bottom elevations of the streambed at the upper and lower extent of the segment, streambed conductance, stream width, sinuosity, and Manning's roughness coefficient. The streambed elevation was estimated on the basis of 1-m DEM's as the minimum elevation within any 250-m reach of the stream. Bottom of the streambed was set at $0.5 \mathrm{~m}$ below the streambed elevation. Stage was allowed to vary as a function of flow in the stream. Streambed vertical hydraulic conductivity values varied from $0.10 \mathrm{~m} / \mathrm{d}$ to $10 \mathrm{~m} / \mathrm{d}$. Low values were assigned where the stream overlies layer 5 and where it overlies silt and clay in layers 2 and 4 . The highest values were assigned where the stream overlies layer 1 and sand and gravel in layers 2 and 4 . Stream width varied from $1 \mathrm{~m}$ in the upper stream reaches to $3 \mathrm{~m}$ along the middle reaches of the San Pedro River and 5 m downstream from Highway 90. Sinuosity was estimated for each segment using the ratio of the length of the simulated stream segment to the actual stream length. A Manning's roughness coefficient of 0.22 was used in calculation of stream stage for all segments.

Simulated inflow to the ground-water system during predevelopment was $84,800 \mathrm{~m}^{3} / \mathrm{d}$ (25,100 acre-feet/yr). Of that total, 58,100 m³/d (17,200 acre-feet/yr) was areal recharge and 26,700 $\mathrm{m}^{3} / \mathrm{d}(7,900$ acre-feet/yr) was inflow from surface water in the San Pedro and Babocomari Rivers. Inflow from surface water is flow that entered the stream from the aquifer in areas where gradients were towards the stream and then reentered the aquifer in downstream reaches where gradients were reversed. Recharge from flood flow in stream channels was not simulated. Simulated ground-water discharge was $84,800 \mathrm{~m}^{3} / \mathrm{d}$ (25,100 acre-feet/yr), including $58,300 \mathrm{~m}^{3} / \mathrm{d}$ (17,300 acre-feet/yr) flow to streams, $1,500 \mathrm{~m}^{3} / \mathrm{d}$ (400 acrefeet/yr) to drains (springs), 2,700 $\mathrm{m}^{3} / \mathrm{d}$ (800 acre-feet/yr) as ground-water underflow across the northern boundary, and 22,300 m³/d (6,600 acre-feet/yr) as evapotranspiration. Simulated stream baseflow at Charleston was 20,300 m³/d (6,000 acre-feet/yr or $8.3 \mathrm{ft}^{3} / \mathrm{s}$ ).

\section{Method and Considerations for Constructing Capture Maps}

Leake and Reeves (2008) described a procedure and considerations for using ground-water flow simulation models to construct maps that illustrate the distribution and timing of capture of natural discharge due to pumping. Three types of maps described in their paper include (1) transient capture from all head-dependent flow boundaries, (2) transient capture from a particular head-dependent flow boundary, and (3) ultimate steady-state capture from a particular head-dependent flow boundary. In this report, maps of transient capture of discharge to all head-dependent flow boundaries were constructed for the Sierra Vista Subwatershed and the Sonora, Mexico, portion of the Upper San Pedro Basin. The methods and considerations for making the maps presented here using the ground-water model by Pool and Dickinson (2007) are described in this section.

\section{Method}

A traditional approach to depicting capture is to use a model to calculate rates of flow from storage and capture through time for withdrawing water at a specific point of interest (fig. 3). Capture can be expressed as a volumetric flow rate or as a dimensionless fraction, defined as change in flow divided by the withdrawal rate that causes the change in flow. If a system responds linearly to ground-water withdrawals, that fraction is independent of the withdrawal rate (Leake and Reeves, 2008). For example, if the capture fraction were 0.4 for a time and location of interest, the capture rate for a withdrawal rate of $100 \mathrm{~m}^{3} / \mathrm{d}$ would be $40 \mathrm{~m}^{3} / \mathrm{d}$, and the capture rate for a withdrawal rate of $1,000 \mathrm{~m}^{3} / \mathrm{d}$ would be $400 \mathrm{~m}^{3} / \mathrm{d}$. Similarly, that same capture fraction could be used to compute changes in inflow to or outflow from the aquifer in response to injection of water. Capture fractions also can be thought of as linear aquifer response functions, similar to those used in management-optimization models (Maddock and Lacher, 1991; Cosgrove and Johnson, 2004).

The first step in computing capture for a withdrawal location is to make a model simulation without added withdrawal to establish baseline values of all water-budget components. The second step is to rerun the simulation with no other 
changes except for an added withdrawal. The third step is to compute changes in water-budget components from the base case for select simulation times. If sufficient information is saved from baseline and subsequent model runs, capture can be computed from specific parts of a system, such as stream reaches of interest or riparian evapotranspiration. Capture from specific parts of the system, such as a stream reach, would require water-budget data from that specific area to be saved from each simulation. This report considers only the total capture within the simulated aquifer system in response to withdrawals and, in the reverse process, total system response to recharge. If a ground-water flow model is not available, a superposition model that simulates changes imposed by withdrawals can be constructed (Cosgrove and Johnson, 2005; Leake and others, 2008). In this approach, all initial water-budget components are zero and transient simulation with a withdrawal results in a direct calculation of capture.

Graphs of capture (fig. 3) are valuable for understanding responses to withdrawals at specific locations. For example, these graphs indicate large differences in capture through time for locations A and B (shown on figure 1). The differences occur because location $\mathrm{A}$ is much closer than location $\mathrm{B}$ to a feature from which capture can occur (in this case the San Pedro River). These graphs, however, do not give resource managers a broader perspective on the effects of withdrawal location and timing over the aquifer as a whole. To better understand capture from an areal perspective, a method was developed to use a ground-water model to compute capture at many locations for a specific time, thereby allowing mapping of potential capture.

Much of the methodology for mapping capture described here is from Leake and Reeves (2008). In a ground-water model constructed with MODFLOW, a well withdrawing water can capture water from features represented by constant- or specified-head cells, as well as features represented with the River Package, the Drain Package, the General-Head Boundary Package, the Stream Package, the Lake Package, the Evapotranspiration Package, and other packages representing head-dependent flow to or from boundaries. In this report, these boundary types are referred to as "head-dependent flow boundaries," meaning that flow to or from the boundary is dependent on the hydraulic head in connected model cells. Of these head-dependent boundary packages, the Upper San Pedro Basin model (Pool and Dickinson, 2007) uses the Drain, Stream, and Evapotranspiration Packages to simulate hydrologic features in the model domain. Additionally, the model uses the Time-Variant Specified-Head Package to simulate flow out of the model domain across several segments of the north boundary. Implications of the use of this specified-head boundary are discussed in the section titled "Considerations."

If a well at a given location withdraws water at rate $\mathrm{Q}_{\text {well }}$, at time $\mathrm{t}$ the capture from $\mathrm{n}$ features will be $\Delta \mathrm{Q}_{1, \mathrm{t}}, \Delta \mathrm{Q}_{2, \mathrm{t}}$, $\ldots \Delta \mathrm{Q}_{\mathrm{n}, \mathrm{t}}$. An individual capture value, $\Delta \mathrm{Q}_{\mathrm{k}, \mathrm{t}}$, is defined as the difference between flow to or from feature $\mathrm{k}$ without the well withdrawing water, $Q_{k, t}$, and the flow to or from the feature in an identical simulation with the withdrawal of water by the well, $\mathrm{Q}_{\mathrm{k}, \mathrm{t}}^{\prime}$. Features subject to capture can be represented

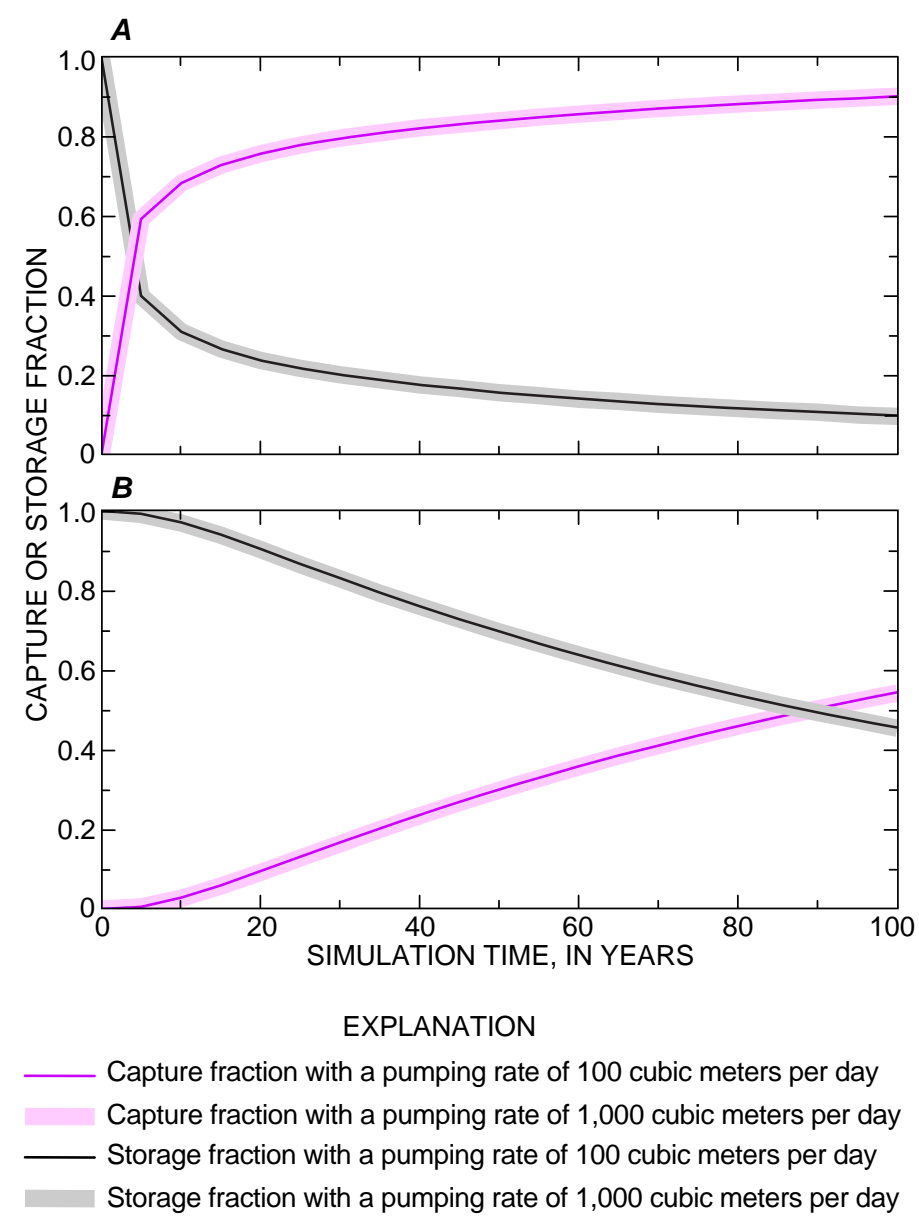

Figure 3. Example capture and storage fraction curves computed by the Upper San Pedro model using discharge rates of 100 and 1,000 cubic meters per day. $A$, curves for a location close to the San Pedro River. $B$, curves for a location distant from the San Pedro River. See figure 1 for locations of curves.

by an individual cell with a head-dependent flow boundary or by a group of cells with a head-dependent flow boundary of a specific type. The change in rate of water going into or out of storage at time $\mathrm{t}, \Delta \mathrm{Q}_{\mathrm{S}, \mathrm{t}}$, is defined as the difference between the rate of flow into or out of storage without the withdrawal of water, $\mathrm{Q}_{\mathrm{S}, \mathrm{t}}$, and the rate of flow into or out of storage in an identical simulation with the withdrawal of water by the well, $\mathrm{Q}_{\mathrm{S}, \mathrm{t}}^{\prime}$. Quantities $\mathrm{Q}_{\mathrm{wel}}, \mathrm{Q}_{\mathrm{k}, \mathrm{t}}^{\prime}, \mathrm{Q}_{\mathrm{k}, \mathrm{t}}, \mathrm{Q}_{\mathrm{S}, \mathrm{t}}$, and $\mathrm{Q}_{\mathrm{s}, \mathrm{t}}^{\prime}$ are volumetric flow rates $\left[\mathrm{L}^{3} / \mathrm{T}\right]$ with a sign convention of negative for withdrawal or outflow, or flow into storage.

A general expression for mass balance accounting for the withdrawal $\mathrm{Q}_{\text {well }}$ at time $\mathrm{t}$ is

$$
\mathrm{Q}_{\mathrm{well}}=\Delta \mathrm{Q}_{\mathrm{S} . \mathrm{t}}+\sum_{\mathrm{i}=1}^{\mathrm{n}} \Delta \mathrm{Q}_{\mathrm{i}, \mathrm{t}}
$$

In this equation, $\Delta \mathrm{Q}_{\mathrm{S}, \mathrm{t}}$ is the difference in total storage change over the entire model area. The summation, $\sum_{i=1}^{n} \Delta Q_{i, t}$ represents the total decrease in outflow to and (or) increase in 
inflow from all head-dependent flow boundaries in the system, or total capture. If a system responds linearly to withdrawals, the capture from a particular withdrawal rate $Q_{\text {well }}^{1}$ can be scaled proportionally to compute capture from another withdrawal rate, $\mathrm{Q}_{\text {well }}^{2}$. Dividing by $\mathrm{Q}_{\text {well }}$, equation 1 can be rewritten as

$$
1.0=\Delta \mathrm{Q}_{\mathrm{S}, \mathrm{t}} / \mathrm{Q}_{\mathrm{well}}+\sum_{\mathrm{i}=1}^{\mathrm{n}} \Delta \mathrm{Q}_{\mathrm{i}, \mathrm{t}} / \mathrm{Q}_{\mathrm{well}}
$$

The first and second terms on the right of equation 2 are the fractions of withdrawal rate that are induced change in storage and induced inflow or outflow (capture), respectively. The volumetric flow rate of capture can be calculated as the product of the withdrawal rate and the second term on the right side of equation 2 .

A map of capture from all head-dependent sources and sinks in the model shows the value of the second term on the right side of equation 2 resulting from placing the withdrawal at different locations. The value of the term will range from 0 to 1 , will likely be higher at a given time for locations close to head-dependent flow boundaries, will be lower at that time for locations distant from head-dependent flow boundaries, and will approach a value of 1 everywhere as $t \rightarrow \infty$.

The general procedure for constructing a map of all capture for a particular time, $t$ (Leake and Reeves, 2008), is as follows:

1. Run the model without the added withdrawal, $\mathrm{Q}_{\text {well }}$, and save values of $\mathrm{Q}_{1, \mathrm{t}}, \mathrm{Q}_{2, \mathrm{t}}, \ldots \mathrm{Q}_{\mathrm{n}, \mathrm{t}}$, and $\mathrm{Q}_{\mathrm{S}, \mathrm{t}}$. These values can be taken from the MODFLOW volumetric mass balance in the listing file or from cell-by-cell budget terms saved to a file.

2. For a location in the region to be mapped, run a transient model with the added withdrawal.

3. For time $\mathrm{t}$, compute $\Delta \mathrm{Q}_{1, \mathrm{t}}, \Delta \mathrm{Q}_{2, \mathrm{t}}, \ldots \Delta \mathrm{Q}_{\mathrm{n}, \mathrm{t}}$ and $\Delta \mathrm{Q}_{\mathrm{S}, \mathrm{t}}$ using computed values of $\mathrm{Q}_{1, \mathrm{t}}^{\prime}, \mathrm{Q}_{2, \mathrm{t}}^{\prime}, \ldots \mathrm{Q}_{\mathrm{n}, \mathrm{t}}^{\prime}$, and $\mathrm{Q}_{\mathrm{S}, \mathrm{t}}^{\prime}$ and saved values of $\mathrm{Q}_{1, \mathrm{t}}, \mathrm{Q}_{2, \mathrm{t}}, \ldots \mathrm{Q}_{\mathrm{n}, \mathrm{t}}$, and $\mathrm{Q}_{\mathrm{S}, \mathrm{t}}$ from step 1.

4. Compute and save the total capture value, $\sum_{i=1}^{n} \Delta Q_{i, t} / Q_{w e l l}$, the storage change value, $\Delta \mathrm{Q}_{\mathrm{S}, \mathrm{t}} / \mathrm{Q}_{\mathrm{well}}$, and the $\mathrm{X}$ and $\mathrm{Y}$ location of the well.

5. If simulations for all locations in the region to be mapped have been run, proceed to step 6; otherwise, select a new location to be mapped and go back to step 2 .

6. Use a GIS or other contouring program to make a contour map of $\sum_{i=1}^{n} \Delta Q_{i, t} / Q_{w e l l}$ for all locations saved.

For the upper San Pedro model, this general procedure was modified by using the published steady-state model run (Pool and Dickinson, 2007) as the base case. This means that in step $1, \mathrm{Q}_{1, \mathrm{t}}=\mathrm{Q}_{1,0}, \mathrm{Q}_{2, \mathrm{t}}=\mathrm{Q}_{2,0} \ldots \mathrm{Q}_{\mathrm{n}, \mathrm{t}}=\mathrm{Q}_{\mathrm{n}, 0}$, and $\mathrm{Q}_{\mathrm{S}, \mathrm{t}}=0$. Also, for efficiency in making many model runs, the transient model used in steps 2 to 5 was a modified version of the published Upper San Pedro Basin model (Pool and Dickinson, 2007). Most of the datasets came from the published steady-state model; however, specific-yield and specific-storage arrays were taken from the transient models. The simulated predevelopment head from the published model was used as the starting head in the new transient model. A single stress period was set up with 1001 -year time steps to simulate a 100-year transient period. Information relating to capture was saved at 5-year intervals, allowing the possibility of creating capture maps for any multiple of 5-year periods.

From the saved information in step 4, a check should be made for each run to determine how close the sum of the two terms on the right side of equation 2 is to a value of 1.0. Leake and Reeves (2008) recommend that if a value differs from 1.0 by more than \pm 0.03 , more care should be taken in getting a better overall mass balance in the model runs in steps 1 and 2 . For the Upper San Pedro model, this was done by adjusting convergence criteria and using a double precision version of MODFLOW. For efficiency, steps 2 to 5 should be automated with a computer program that runs the model repeatedly, each time incrementing the well location, computing capture values, and saving results.

\section{Considerations}

Ideally, all head-dependent flow boundaries should represent physical features in the hydrologic system from which capture can occur. If a model includes head-dependent flow boundaries that are not physical hydrologic features, for example specified-head cells at the lateral boundary of a model, the mapped capture values can be erroneous where withdrawals by wells induce inflow from or reduce outflow to those boundaries. If such boundaries exist, care must be taken to limit the extent of the capture map to locations where capture is most likely to occur from actual hydrologic features represented with head-dependent flow boundaries. According to Leake and Reeves (2008), an estimate of the extent of the region to be mapped can be made by analyzing transient capture from a particular head-dependent flow boundary that does not represent an actual physical hydrologic feature. They indicate that where the value of the function $\Delta Q_{k, t} / Q_{\text {well }}$ for nonphysical hydrologic feature $\mathrm{K}$ is small, say less than 0.1 , then effects of the nonphysical boundary for that withdrawal location are minimal.

Similarly, if a model includes no-flow boundary segments that do not represent physical impermeable boundaries, mapped capture values may be erroneous. Care should be taken not to map capture values near these nonphysical boundaries. One method of analysis to quantify the effects of an artificial no-flow boundary involves comparison of results with and without the boundary and determining the area over which mapped capture patterns are the same or nearly the same. Because this involves extending the model area, it is a difficult analysis to carry out. Another method involves introducing artificial head-dependent boundaries at the locations of the artificial no-flow boundaries. The boundary heads should be set so that computed heads at the added headdependent boundary cells are the same as computed heads at 
the same locations in the simulation with no-flow boundaries. An analysis as described earlier for artificial head-dependent boundaries can be carried out. Both of these methods involve significant modifications to the flow model that were beyond the scope of this study.

The northern boundary of the Upper San Pedro model includes both no-flow segments that do not represent physical impermeable boundaries and head-dependent segments that do not represent physical hydrologic features. For this reason, capture maps presented in this report do not extend to the northern boundary of the model. Similarly, almost the entire model perimeter along a surface-water divide, also assumed to be a ground-water divide, was simulated as a noflow boundary. The effects of a well withdrawing water near a ground-water divide would be to move the divide away from the well. Treating the divide as a no-flow boundary tends to overestimate capture in the modeled area, especially for withdrawal locations near the no-flow boundary. For the San Pedro model, most of the area mapped for capture or riparian-system response is not close to ground-water divides that are simulated as no-flow boundaries. An exception is along the southern end of the model near Cananea, Mexico. The simulated capture presented in the next section is close to this suspected ground-water divide; however, capture and riparian-system response in this area are in the lowest range of fractional values shown. A more rigorous treatment of the ground-water divide, therefore, would not change the appearance of the map.

Depending on the size of the region to be mapped, hundreds or even thousands of model runs may be required to construct a capture map. If possible, the model should be simplified to run efficiently for the period of time for which capture will be computed. Mapping capture does not necessarily require capture calculations for every grid cell. For example, the horizontal grid spacing of the Upper San Pedro model was $250 \mathrm{~m}$ in both the north-south and east-west directions. Computing capture for each cell in a horizontal domain representing one or more model layers would have resulted in a finer spatial resolution than is needed to construct a capture map. Instead, capture values were computed for horizontal locations at every fourth cell, resulting in capture values at 1-km intervals.

In the following section, this report presents maps showing responses to two types of system perturbations. For the first map, responses to withdrawals from the lower basinfill sand and gravel unit (layer 4) are shown for the extent of active cells in layer 4, except for an area near the northern boundary where nonhydrologic head-dependent boundaries were used. For the second map, responses to recharge in the uppermost active cells over the areal extent the lower basinfill sand and gravel unit (layer 4) were computed. The second type of map, concerning recharge, is technically not a map of capture, but if the system responds linearly to injections and withdrawals, the magnitude of results from injection would be the same as results from withdrawal.

As described previously, the mass balance for capture calculations should be as close to zero as possible. Leake and Reeves (2008) recommend that the quantity difference between total rate of inflow and total rate of outflow (in the MODFLOW listing file, the rate listed as "IN-OUT" under "rates for this time step" in the volumetric mass balance) should be less than a few percent of the withdrawal rate of the added well, $\mathrm{Q}_{\text {well }}$. For the San Pedro model as applied in this report, this quantity was kept small by adjusting closure criteria of the numerical solver and by using a double precision version of MODFLOW-2000.

Also as discussed previously, if a system responds linearly to withdrawal or injection, the terms on the right side of equation 2, $\Delta \mathrm{Q}_{\mathrm{S}, \mathrm{t}} / \mathrm{Q}_{\mathrm{well}}$ and $\sum_{\mathrm{i}=1}^{\mathrm{n}} \Delta \mathrm{Q}_{\mathrm{i}, \mathrm{t}} / \mathrm{Q}_{\text {well }}$ will not vary as a function of $Q_{\text {wel }}$. Nonlinear responses to withdrawal or injection of water can occur from changes in aquifer saturated thickness. Another way for nonlinearity to occur involves functional relationships between head and boundary flow for the Drain, Stream, and Evapotranspiration Packages. For these and other head-dependent flow packages in MODFLOW, water-level changes in response to withdrawal or injection can be within nonlinear portions of the associated flow functions. For example, the Evapotranspiration Package includes an extinction depth to ground water below which evapotranspiration ceases and another level above which evapotranspiration becomes constant. Head changes from withdrawal or injection that cross these thresholds result in nonlinear responses. A basinwide analysis of nonlinearity was not carried out in this study; however, some indication of linearity of responses can be seen in capture curves for two locations in the model domain (fig.3). The capture and storage-change fractions,

$\Delta \mathrm{Q}_{\mathrm{S}, \mathrm{t}} / \mathrm{Q}_{\mathrm{well}}$ and $\sum_{\mathrm{i}=1}^{\mathrm{n}} \Delta \mathrm{Q}_{\mathrm{i}, \mathrm{t}} / \mathrm{Q}_{\text {well }}$, are nearly the same for $Q_{\text {well }}$ values of 100 and $1,000 \mathrm{~m}^{3} /$ day. As a general rule, if nonlinearity exists, boundary response from withdrawal (capture) will be overestimated for a specific time and boundary response from injection will be underestimated.

\section{Results}

Maps were constructed for total capture of discharge to streams, evapotranspiration, and springs that results from withdrawal and recharge at a rate of $100 \mathrm{~m}^{3} / \mathrm{d}$. Maps showing capture after 10 and 50 years of withdrawal (figs. $4 \mathrm{~A}$ and $4 B$ ) from layer 4 and recharge to the uppermost active cell in model layers 1, 2, and 4 (figs. 5A and 5B) are discussed in this report. No withdrawals or recharge were applied to model layer 5 in this analysis; therefore, the maps show only results for the extent of model layer 4 . In addition, simulation of withdrawals from some cells near the margins of layer 4 did not produce reliable results because cells with a small initial saturated thickness go dry when a withdrawal is placed at that location. For simulations of withdrawal from layer 4, less than 7 percent of cells went dry before 50 
years of withdrawal at a rate of $100 \mathrm{~m}^{3} / \mathrm{d}$. Figures $4 A$ and $4 B$ do not show results for cells that went dry. The maps use a red-blue spectral color scheme to delineate total capture rates at 10 and 50 years as a fraction of withdrawal and recharge stress rates. For each map, blue colors indicate a greater amount of water available to the San Pedro River riparian system and red colors indicate a lesser amount of water available to the system. Blue colors indicate a lower fraction of capture for the withdrawal case, but a greater fraction of increased ground-water discharge at streams, evapotranspiration, and springs for the recharge case. For locations where recharge was put into layer 4, results are of the same magnitude as results from withdrawal at the same locations. Differences at other locations are a result of recharge being placed into a different layer from that of withdrawal.

Analysis of withdrawals from layer 4 and recharge to layers 1, 2, and 4 eliminates some areas of ground-water withdrawal that lie slightly beyond the lateral margins of layer 4. Important regions of layer 5 that can be of interest occur near the Huachuca Mountains in the Sierra Vista area and near the San Pedro River near Charleston. Withdrawals from regions of layer 5 that lie beyond the lateral extent of layer 4 in the Sierra Vista area will result in slightly greater delay in capture than shown in the nearest region of layer 4 on figure 4 . Very little productive aquifer and no groundwater withdrawals occur in the region represented by layer 5 in the Charleston area. Any potential withdrawals or recharge in this region would result in a more rapid influence on streamflow and evapotranspiration than occurs at the nearest shaded region shown on figures 4 and 5 .

The maps show that withdrawal near the Babocomari and San Pedro Rivers will generally result in earlier and more substantial capture of discharge of ground water to streams, evapotranspiration, and springs than withdrawal at greater distance from the river. Similarly, recharge applied near the Babocomari and San Pedro Rivers will generally result in earlier and more substantial ground-water discharge to these features. However, the timing and magnitude of simulated capture rates are not symmetric about the streams and vary somewhat over the length of the streams. This variability in results is attributed to spatial variations in the geometry and hydraulic properties of the aquifer system. In particular, variations in aquifer thickness and extent of a low permeability silt and clay layer (fig. 1) cause much of the spatial variation in response in the central part of the Sierra Vista Subwatershed. The effect of the silt and clay layer is most evident in maps of capture resulting from withdrawals in model layer 4 (figs. $4 \mathrm{~A}$ and $4 \mathrm{~B}$ ), but it also occurs in the maps of enhanced discharge resulting from recharge (figs. $5 \mathrm{~A}$ and $5 B$ ). The silt and clay layer underlies the river between Hwy 90 and Hwy 92. Withdrawal from layer 4 beneath the silt and clay in this area results in a delay in capture in comparison to adjacent areas near the river. For example, 10 years of withdrawals in areas north of Hwy 90 and south of Hwy 92 near the river result in overall capture that is equivalent to 70 percent or more of the withdrawal rate, but similar withdrawal rates in the intervening area result in capture of less than 50 percent of the withdrawal rate. Eventually, withdrawals at any location will result in capture that is equivalent to 100 percent of the withdrawal rate. This trend toward 100 percent capture can be seen by comparing maps for withdrawal at 10 and 50 years in figure 4; the area of red adjacent to the San Pedro River is increasing with time. At the south end of the modeled area, capture at 50 years is still relatively low. This underscores the fact that timing of capture is highly dependent on proximity of withdrawals to head-dependent features at which water can be captured.

\section{Applicability and Limitations}

The procedure described here is designed to produce a depiction of responses to withdrawal or recharge over large areas of an aquifer. The results are meant to help resource managers and the general public understand patterns of response that are based on features represented in the basinscale model of portions of the Upper San Pedro Basin by Pool and Dickinson (2007). The distributions shown on maps do not necessarily mean that withdrawal and (or) recharge at all locations is appropriate or even technically feasible. In the generation of maps presented in this report, an automated procedure sequenced through cells at 1-km intervals regardless of properties such as hydraulic conductivity and storage coefficient. Depending on the values of these properties, the applied withdrawal or recharge rate may cause unrealistic results. During the process of computing capture from withdrawals, locations for which withdrawal caused a cell to go dry were saved for later analysis, but in the procedure for computing response to recharge, no check was made to determine whether or not recharge at the rate used would cause unrealistically high water levels. Site-specific withdrawal or recharge projects may require studies using local hydrologic conditions in the area of interest.

Simulated capture rates were linear with respect to withdrawal rates at selected locations for rates ranging from 100 to 1,000 m³/d (fig. 3). Effects of many wells or wells of significantly higher withdrawal and injection rates, however, could result in nonlinear responses. Use of the maps in this report should be thought of as depicting responses for an individual well withdrawing or injecting water in a system that is relatively unperturbed by other withdrawals and injections. Stated another way, the maps provide a spatial depiction of the susceptibility of the aquifer system to capture starting from the steady-state condition. To the extent that development has not greatly changed transmissivity and the locations of head-dependent boundaries, the results also apply to the developed condition. 


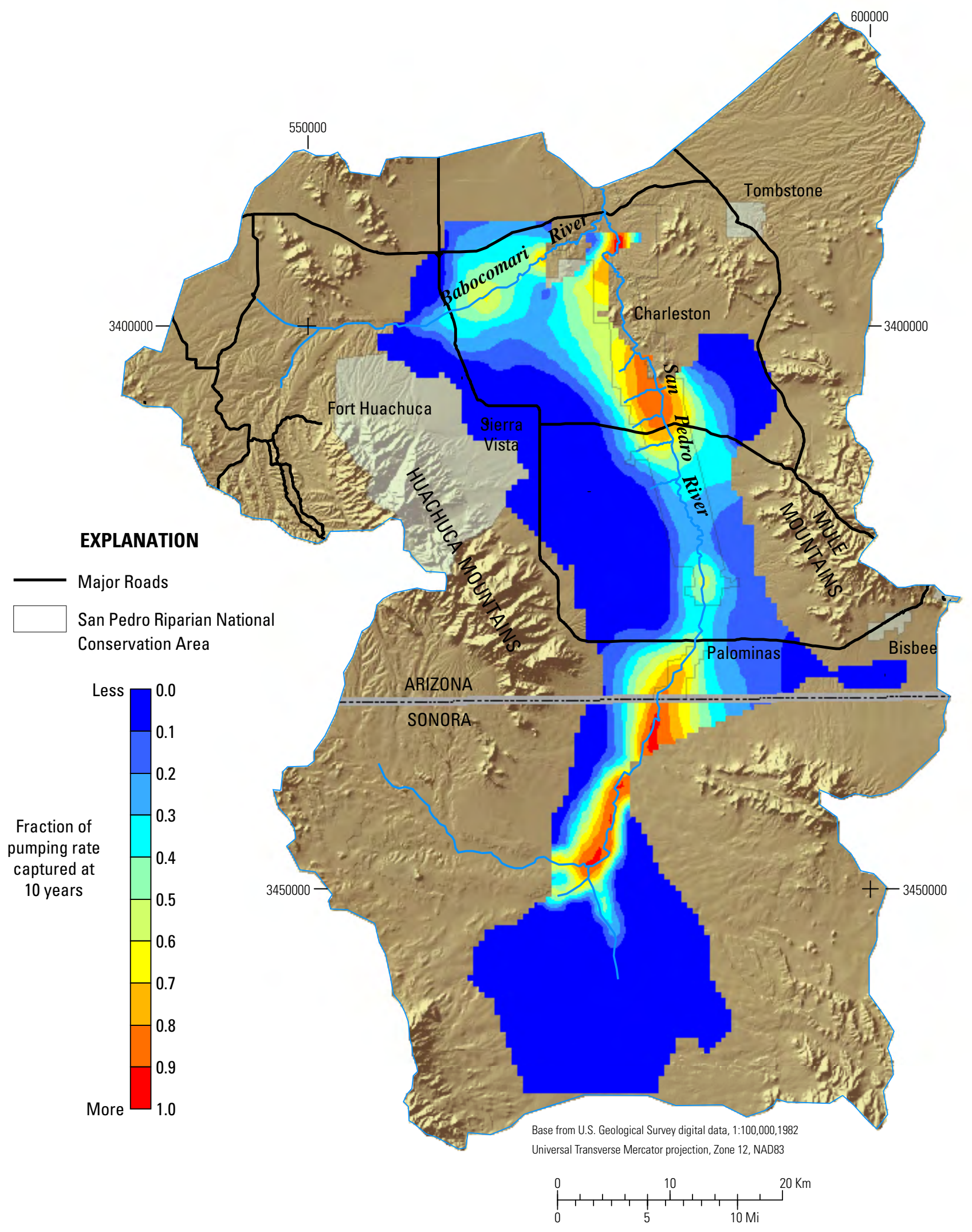

Figure 4A. Computed capture of streamflow, riparian evapotranspiration, and springflow that would result for withdrawal of water from model layer 4 at a constant rate for 10 years. The color at any location represents the fraction of the withdrawal rate by a well at that location that can be accounted for as changes in outflow from and or inflow to the aquifer for model boundaries representing streams, riparian vegetation, and springs. 


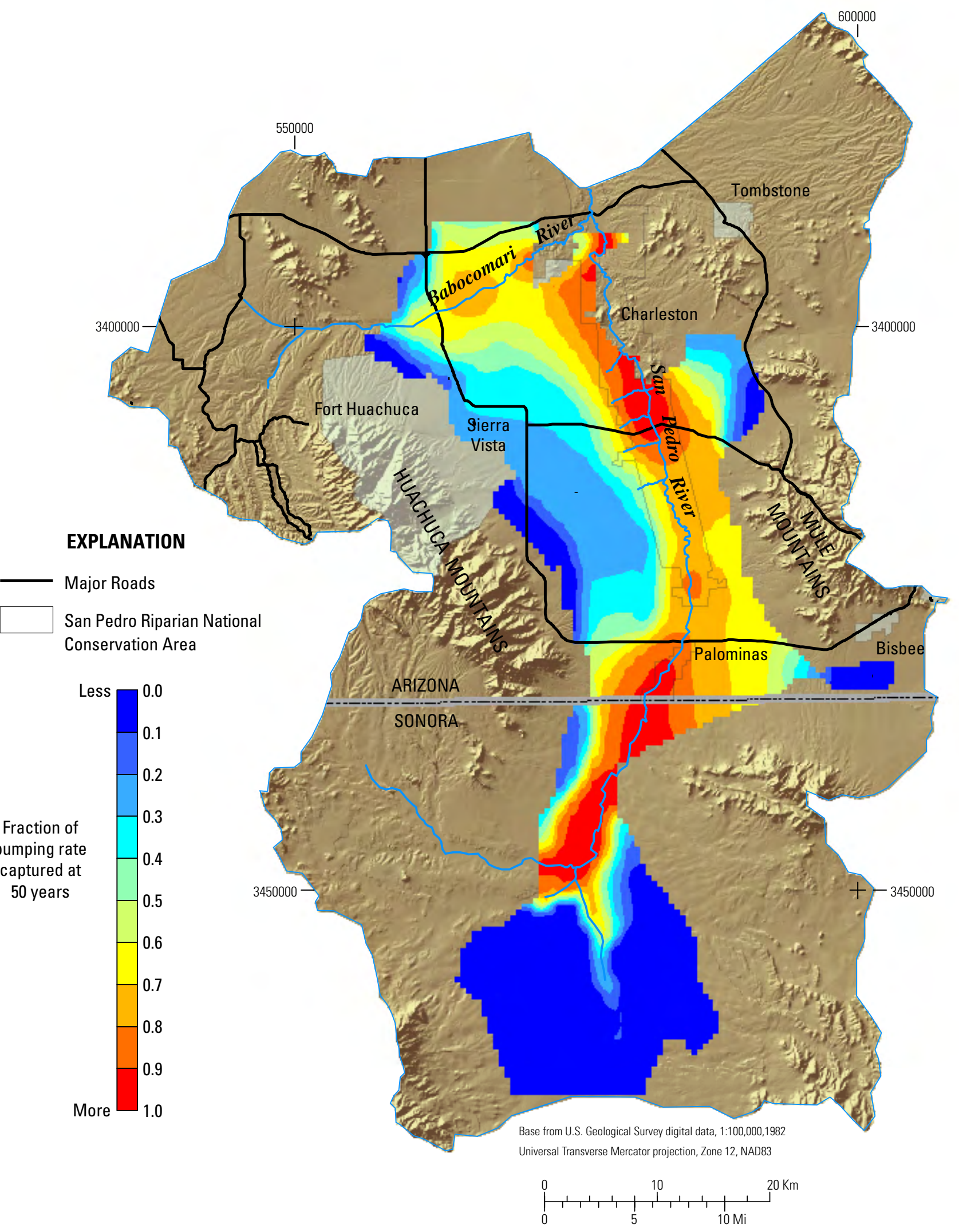

Figure 4B. Computed capture of streamflow, riparian evapotranspiration, and springflow that would result for withdrawal of water from model layer 4 at a constant rate for 50 years. The color at any location represents the fraction of the withdrawal rate by a well at that location that can be accounted for as changes in outflow from and or inflow to the aquifer for model boundaries representing streams, riparian vegetation, and springs. 


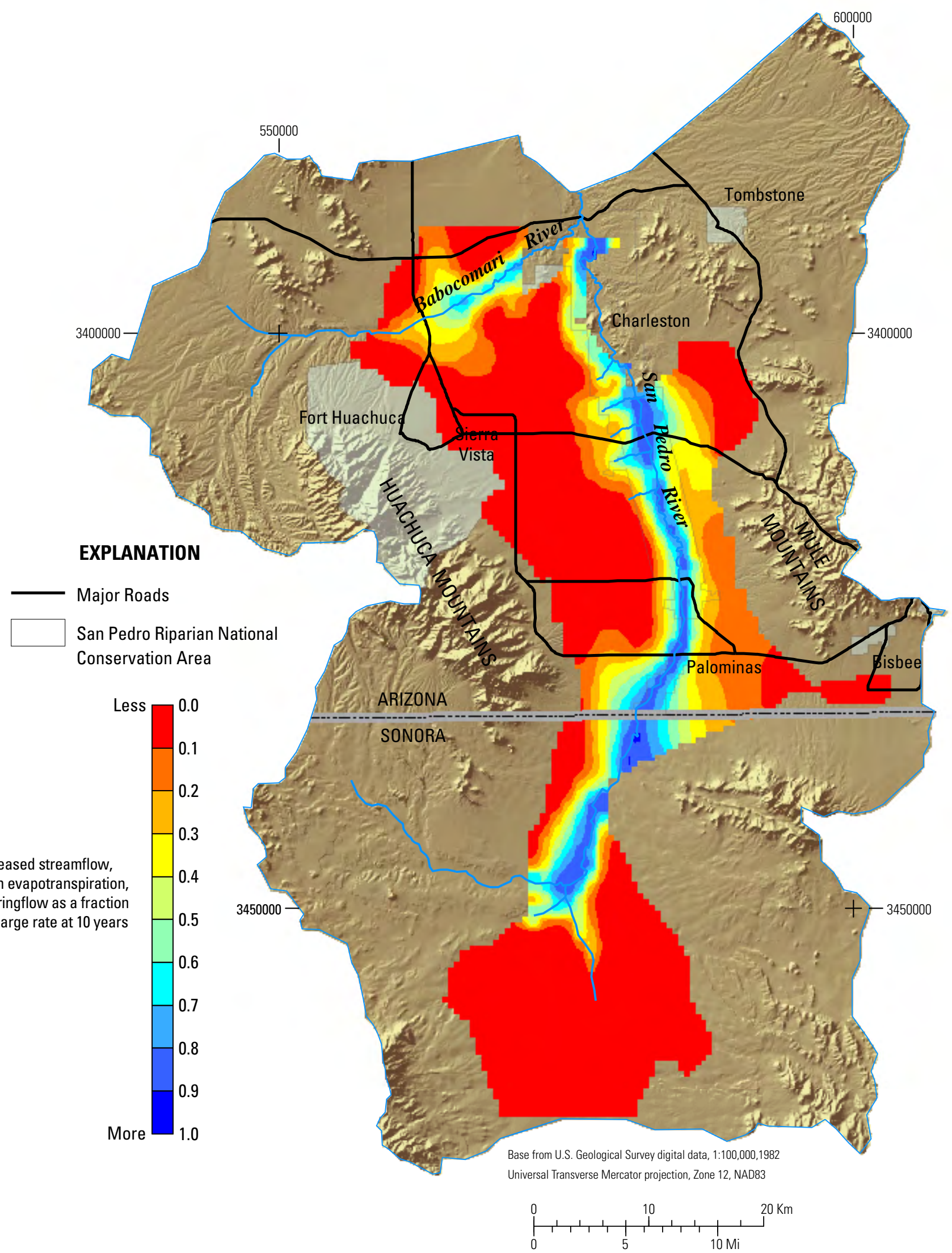

Figure 5A. Computed increase of streamflow, riparian evapotranspiration, and springflow that would result for recharge of water to the uppermost model layer at a constant rate for 10 years. The color at any location represents the fraction of the recharge rate at that location that can be accounted for as changes in outflow to model boundaries representing streams, riparian vegetation, and springs. 


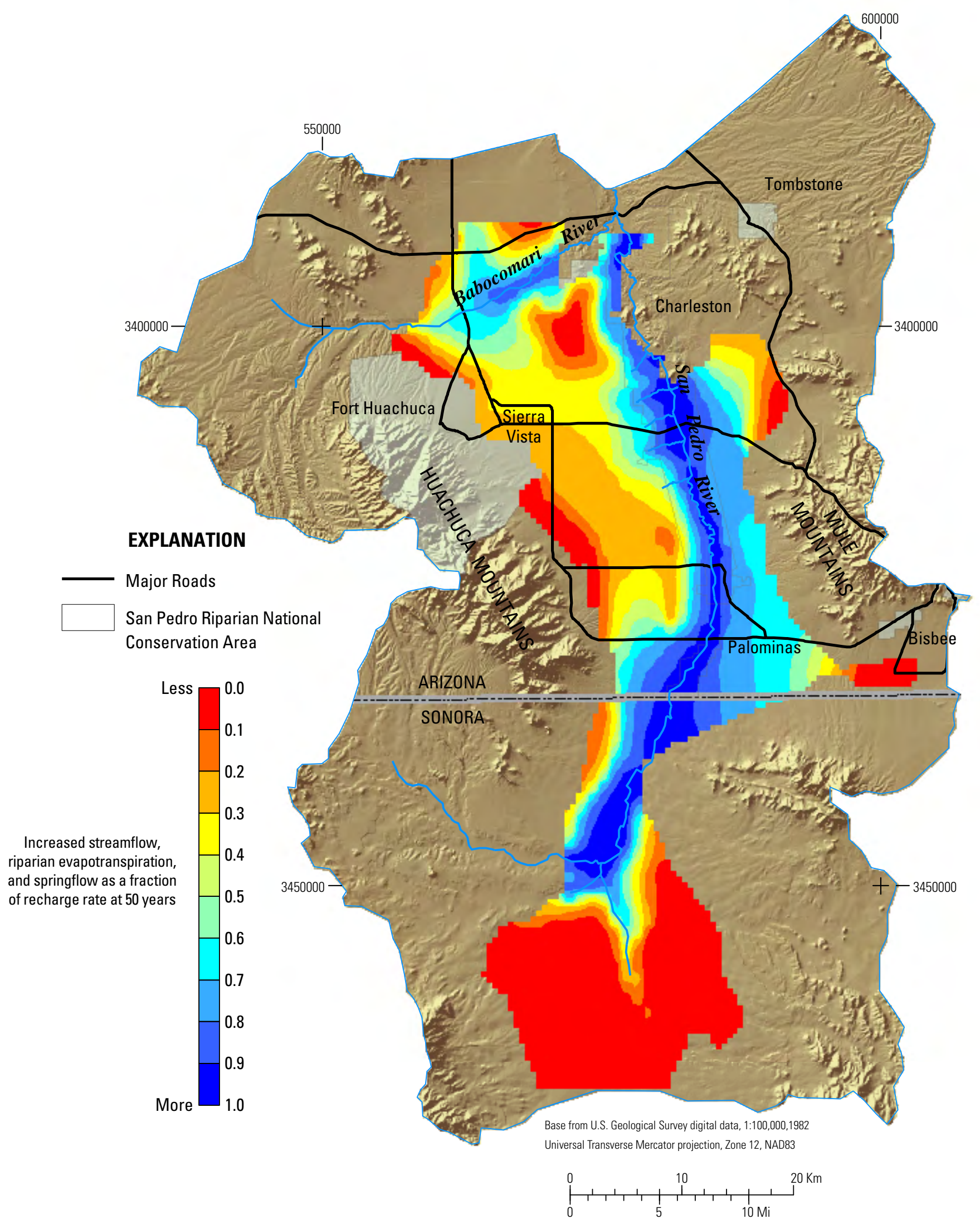

Figure 5B. Computed increase of streamflow, riparian evapotranspiration, and springflow that would result for recharge of water to the uppermost model layer at a constant rate for 50 years. The color at any location represents the fraction of the recharge rate at that location that can be accounted for as changes in outflow to model boundaries representing streams, riparian vegetation, and springs. 


\section{Summary}

One of the possible undesired consequences of withdrawal of ground water is reduction of water available to connected streams, springs, and riparian trees dependent on ground water. This reduction is referred to as "capture" or "streamflow depletion." The concept of capture is of particular relevance in the Upper San Pedro Basin in southeastern Arizona, which includes both a growing population dependent on ground water and a federally protected riparian system. To help study ground-water/surface-water interaction in the area, Pool and Dickinson (2007) constructed a ground-water flow model that simulates a predevelopment condition and a period of transient development. One approach to studying capture using the model is to compute curves of capture versus time for selected locations of withdrawals. A method developed for this study, however, allows mapping capture for specific times of interest. Capture maps made using this method allow water managers to better see how withdrawal location affects the timing of capture. For the Upper San Pedro Basin, capture maps were developed for withdrawal periods of 10 and 50 years. The maps show greatest capture near the San Pedro River for both times, and an increase in capture between 10 and 50 years. Results, however, are not symmetrical around the river and are variable along the length of the river because of a clay layer that is present in some locations between the withdrawal interval in the lower basin-fill aquifer and the river. Also, maps were constructed to show the response to artificial recharge to the water table in the basin-fill aquifer. Patterns of response to recharge are similar to those for capture at 10 and 50 years.

\section{References Cited}

Consultores en Agua Subterranea S.A. for Mexicana de Cananea, S.A. de C.V., 2000, Actualización del estudio geohidrológico de las cuencas del Rio San Pedro y norte del Rio Sonora en Cananea, Son.: 136 p, 5 appendices.

Cosgrove, D.M., and Johnson, G.S., 2004, Transient response functions for conjunctive water management in the Snake River Plain, Idaho: Journal of the American Water Resources Association, v. 40, no. 6, p. 1469-1482.

Cosgrove, D.M., and Johnson, G.S., 2005, Aquifer Management Zones Based on Simulated Surface-Water Response Functions: Journal of Water Resources Planning and Management, v. 131, no. 2, p. 89-100.
Glover, R.E, and Balmer, G.G., 1954. River depletion resulting from pumping a well near a river: Transactions American Geophysical Union, v. 35, no. 3, p. 468-470.

Harbaugh, A.W., Banta, E.R., Hill, M.C., and McDonald, M.G., 2000a, MODFLOW-2000, the U.S. Geological Survey modular ground-water model—user guide to modularization concepts and the ground-water flow process: U.S. Geological Survey Open-File Report 00-92, 121 p.

Harbaugh, A.W., Banta, E.R., Hill, M.C., and Anderman, E.R., 2000b, MODFLOW-2000, the U.S. Geological Survey modular ground-water model - user guide to observation, sensitivity, and parameter-estimation processes and three post-processing programs: U.S. Geological Survey OpenFile Report 00-184, 209 p.

Leake, S.A., Greer W., Watt, D., and Weghorst, P., 2008, Use of superposition models to simulate possible depletion of Colorado River water by ground-water withdrawal: U.S. Geological Survey Scientific Investigations Report 20085189, 25 p.

Leake, S.A., and Reeves, H.W., 2008, Use of models to map potential capture of surface water by ground-water withdrawals: Golden, Colorado, International Groundwater Modeling Center, Proceedings of MODFLOW and More 2008, p. 204-208.

Maddock, T.M. III, and Lacher, L., 1991, Drawdown, velocity, storage, and capture response functions for multiaquifer systems: Water Resources Research, v. 27, no. 11, p. 2885-2898.

Pool, D.R., and Dickinson, J.E., 2007, Ground-water flow model of the Sierra Vista Subwatershed and Sonoran portions of the Upper San Pedro Basin, southeastern Arizona, United States, and northern Sonora, Mexico: U.S. Geological Survey Scientific Investigations Report 2006-5228, 48 p.

Prudic, D.E., 1989, Documentation of a computer program to simulate stream-aquifer relations using a modular, finite-difference, ground-water flow model: U.S. Geological Survey Open-File Report 88-729, 113 p.

Theis, C.V., 1940, The source of water derived from wells: Civil Engineering, v. 10, no. 5, p. 277-280. 


\section{Appendix}

At the request of some stakeholders in the Sierra Vista subwatershed of the upper San Pedro Basin, the authors have added the map found in this appendix that shows capture after 100 years of withdrawal from layer 4 (fig. A1). As with the 10- and 50-year capture maps in figs. 4A and 4B, no withdrawals were applied to model layer 5 ; all the maps show only results for the extent of model layer 4 . For the 50-year capture map (fig. 4B), about 7 percent of cells went dry during the simulation, while for the 100-year capture map (shown here, fig. A1), about 11 percent of cells went dry before 100 years of withdrawal at a rate of $100 \mathrm{~m}^{3} / \mathrm{d}$. These cells are found around the model perimeter in fig. A1 and are shown in black. For further discussion related to the meaning and use of this map, please see the discussion of results and of applicability and limitations found in the body of the report, beginning on p. 8 .

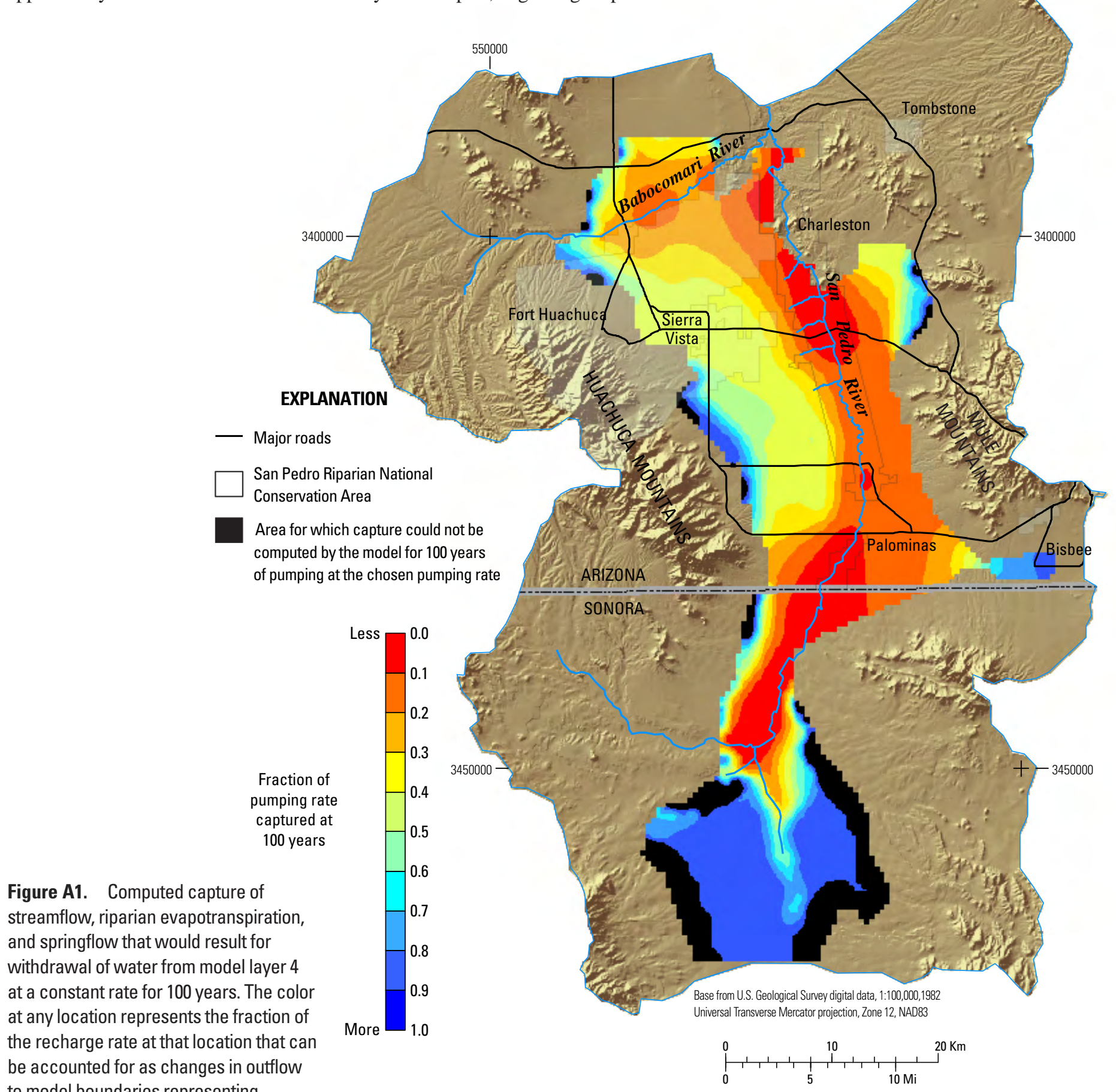

to model boundaries representing streams, riparian vegetation, and springs. 


\section{营}

बิ

ํㅡㄹ

웋

.

틀

串

票

$\vec{a}$

咅

ISBN 1-4113-2331-9 